\title{
THE CYTOLOGICAL EXAMINATION OF BRONCHIAL SECRETION
}

\author{
By WALTER STRUPLER (Berne)*
}

THE rapid increase of bronchogenic carcinoma in the first half of this century is alarming. In Igoo 5 per cent. of all deaths due to carcinoma were bronchogenic. Today the number has risen to 18 per cent.

The apparent changes may be partially due to better diagnostic procedures but there is undoubtedly a real increase. This is due in part to a rise in the average age of the population. In the last fifty years life expectancy has risen from 47 to 63 years. Another possible reason for the augmentation may be the increasing influence of carcinogenic factors, especially the wide-spread abuse of the tobacco habit. That may explain the increase of bronchial cancer in women.

Ætiology and pathogenesis are still insufficiently investigated. Diagnostic procedures and treatment have been improved, but there must be a greater effort to achieve early diagnosis.

Two decades ago patients with pulmonary carcinoma, almost without exception, had a fatal prognosis. Hence the earlier diagnosis and the possibility of better treatment have multiplied the number of cures affected. A great number of operable cases can today be saved thanks to the modern methods of anesthesiology, prevention of operative shock and the improvement of thoracic surgery.

Parallel to improvement in treatment, there has been a corresponding development of the diagnostic procedures. The $\mathrm{X}$-ray examinations have been supplemented by bronchography, tomography, kymography, and so forth. A new method for the functional detection of centrally situated lung tumour is now advocated by the French authors, the so-called cinedensigraphy.

For the more important operations with high vital risk verification by histological examination is indicated. Systematic bronchoscopy done with the aid of various optics, allows the visualization of a maximum of 65 to 75 per cent. The greater part of bronchial cancers arise from the larger bronchi which can be reached by endoscopy.

As the statistics on numerous cases show, a biopsy with a positive finding is only possible about 50 per cent. of the time. A biopsy in the

* From the University of Berne, Ear, Nose and Throat Department (Medical Director: Prof. F. Escher). 


\section{Walter Strupler}

upper lobe bronchus could be done with the aid of an artificial pneumothorax. Sometimes material for histo-pathologic examination can be obtained by a blind bronchial curettage.

This leaves a great percentage of proven tumours which cannot be verified by these methods. This diagnostic gap can often be filled by cyto$\log$.

The larger the tumour and the closer it lies to the hilus, the greater is the

1.

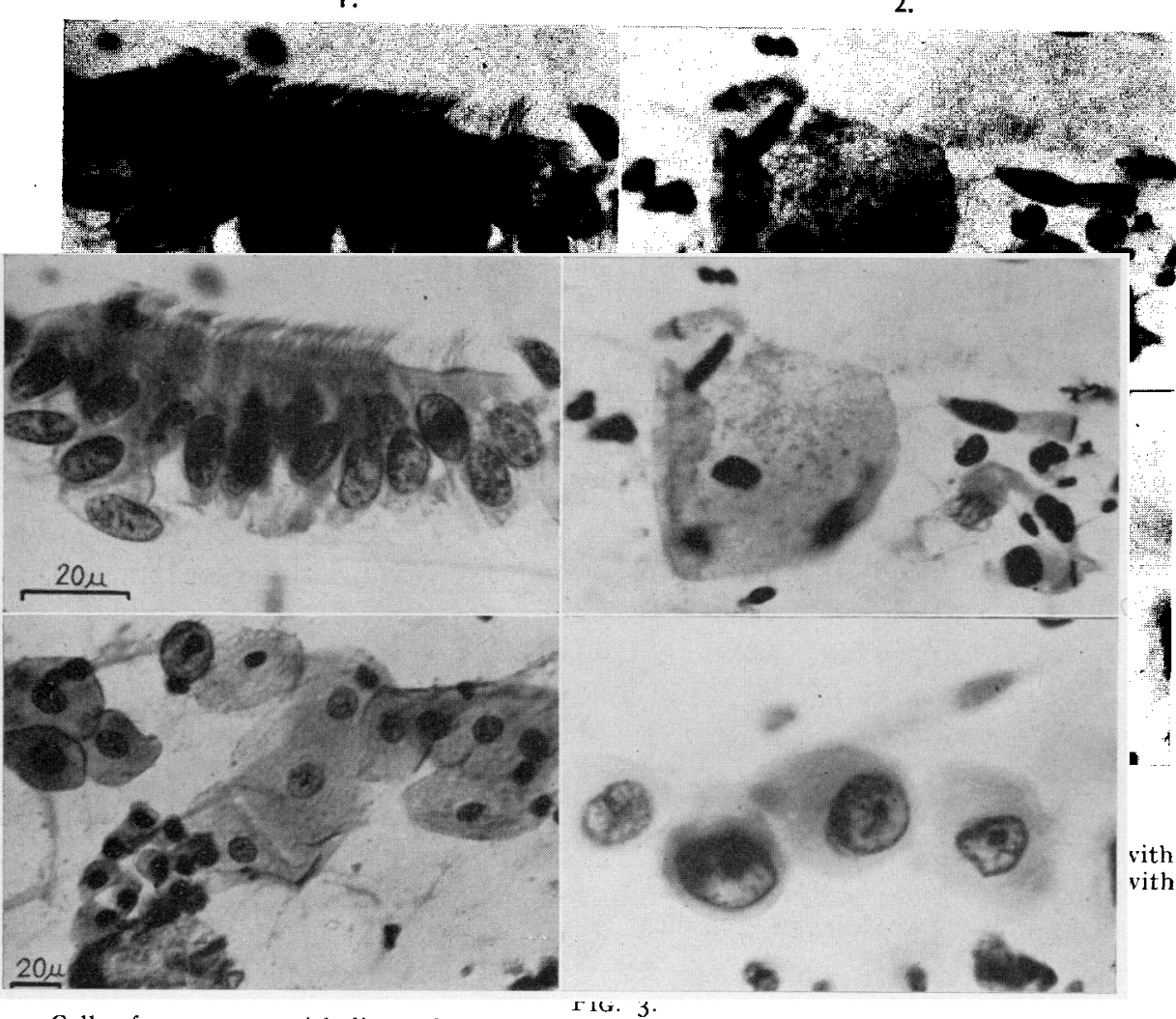

Cells of squamous epithelium of respiratory tract. Cells of deep, intermediate and superficial layer. Note difference in size and density of cytoplasm and nuclei (middle power magnification).

FIG. 4 .

Cells of squamous cell carcinoma of the lung. Fairly abundant cytoplasm. Large nucici slightly varying in size and shape. No marked increase of chromatin.

possibility of obtaining a positive biopsy. But in respect to treatment, the closer a tumour lies to the hilus and the greater its size, the less favourable must be the prognosis. The less accessible a tumour is for biopsy the greater is the chance that it would be a good operative risk.

The examination of bronchial secretion is therefore an important 


\section{The Cytological Examination of Bronchial Secretion}

supplement to the other methods of tumour detection. This method of diagnosis is based on the fact that in all epithelia, including the mucosa of the respiratory tract, an exfoliation of the superficial layers normally takes place. This applies in an especially high degree to the stratified squamous epithelium. This same desquamation is found in many epithelial tumours before actual decay, before the expectoration of gross tumour particles has set in.

5.
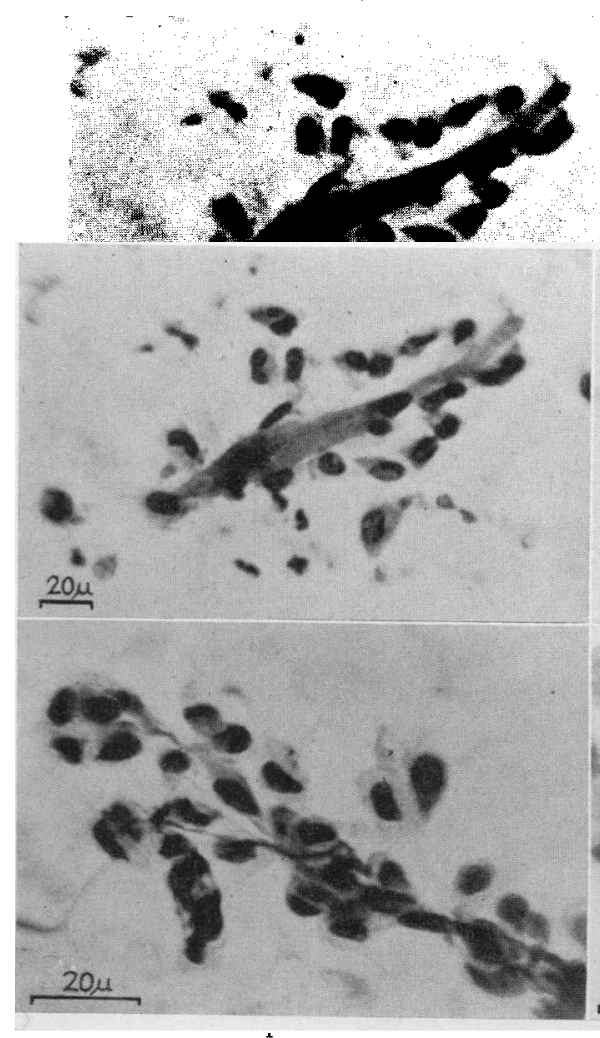

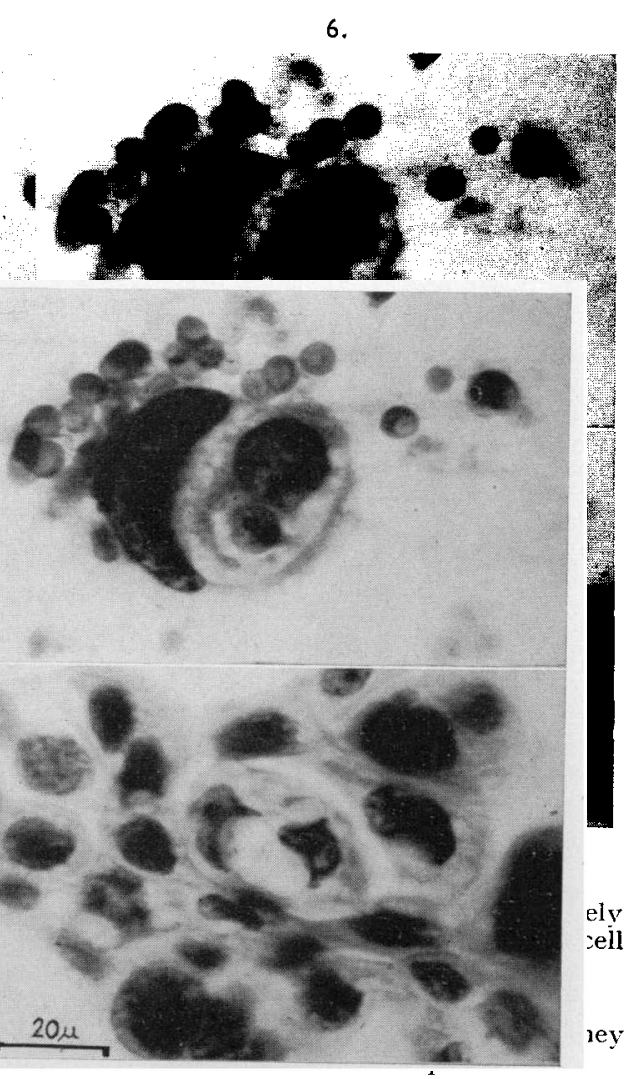

Fig. 7 .

Cells of oat cell carcinoma. Relatively small variation in shape and size of the cells. Indistinct cell borders. Scarce cytoplasm. Sharp nuclear borders. Long oval nuclei.

FIG. 8.

Big cluster of cells of adenocarcinoma. Allusion to acinus formation. Isolated cells are very difficult to distinguish from other tumour cells. Slight vacuolization of the grouped cells. The appearance of nuclei is characteristic of any malignant cell.

Highly experienced cytologists are able to diagnose up to 85 per cent. of lung cancer by the examination of the cell content of the bronchial secretions. Sometimes it is even possible to predict the type of tumour.

Nearly a century ago the first report was made of the occurrence of macroscopically visible particles of tumour in the expectoration of patients 


\section{Walter Strupler}

with lung cancer. Other authors subsequently reported similar observations. The gross fragments of malignant growth were worked up by the ordinary histologic technique. Later on sputum was treated in the same manner as other histological specimens by means of embedding and sectioning. Generally this method was not considered of consistent diagnostic value.

The first cytological study of sputum was made by Hampelin in 1887 in a case of pulmonary cancer. In I9I 8 he gave a second report of 25 carcinoma of the lung. In $\mathrm{I}_{3}$ cases he detected isolated cancer cells in unstained smears of fresh sputum. Though he stressed the diagnostic value of cytology of sputum, little attention was paid to this method.

In I935 Dudgeon and Wrigley of London introduced the wet film method; this procedure consists of fixing the wet smear in a solution without first drying. The same or similar technique was employed by a number of other investigators, including Wandall.

In the development of cytology Papanicolaou has earned great merit. After having studied vaginal secretions in relation to ostrus cycle abnormalities, he began in I9I 8 to study the secretions of the female genitalia in respect to malignant growth. He stressed the diagnostic importance of exfoliated cells in secretions surrounding carcinomas with a free surface; for this reason he placed great value on the systematic analysis of all accessible body fluids.

Furthermore Papanicolaou has developed an excellent polychrome staining technique which facilitates the recognition of malignant cells.

By means of a series of coloured photo-micrographs the principal criteria for cytological identification of tumour cells are demonstrated. Here only a reproduction of a reduced number of uncoloured pictures is possible.

These micrographs transmit an idea of the normal and pathological cellular content of bronchial secretions.

The short exposé does not allow demonstration of the many variations and deviations from the classical cytological pictures. This report consists of an examination of the principal cytological findings in bronchial secretions.

The basis of the cyto-diagnostic procedures is the knowledge of the normal and the pathological cellular content of this particular body secretion. We have to imagine sputum or selectively aspirated bronchial secretions as a reservoir of cells shed from the lining epithelia of the respiratory tract. Sputum specimens are contaminated with saliva, secretions of the pharynx and oesophagus and generally contain abundant cells of stratified squamous epithelium. The topical source of the pavement cells cannot be determined, for in addition to the above mentioned sources of cellular material the vocal cords and the epiglottis are lined with similar epithelium. 


\section{The Cytological Examination of Bronchial Secretion}

It is not well known that stratified squamous epithelium occurs normally in the tracheo-bronchial tree on the carina of the windpipe as well as on the carina of the lobar bronchi.

9.

10.

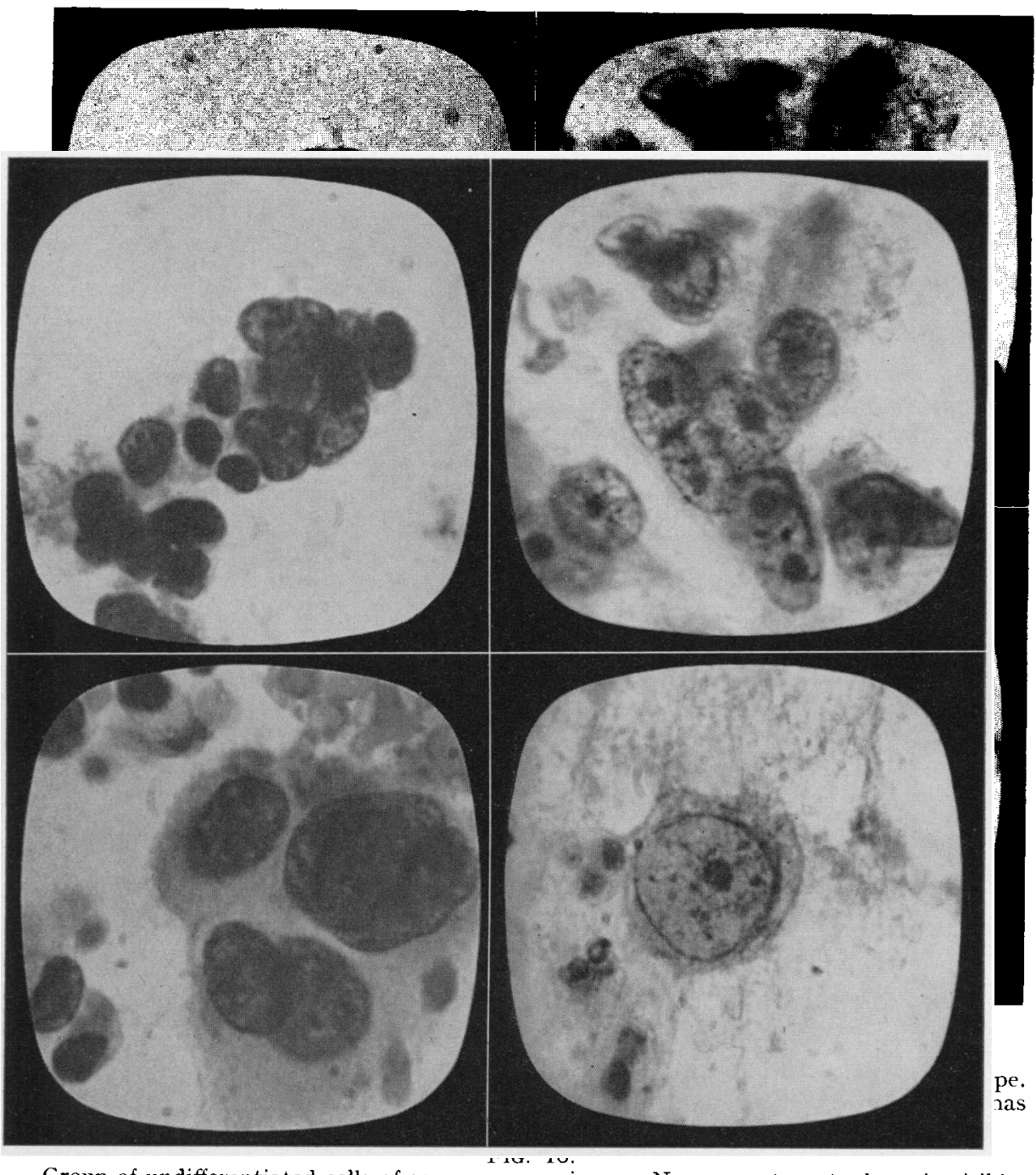

Group of undifferentiated cells of squamous carcinoma. No or scanty cytoplasm is visible. These cells with their giant nucleoli fulfill all criteria of undifferentiated epithelial malignancy.

FIG. II.

Squamous carcinoma. Large cells with marked hyperchromasia and anisokaryosis. Cloudy pattern of chromatin.

FIG. I2.

Squamous carcinoma. Discrete cornified cell with a large nucleus. Distinct nuclear border. Enlarged dark nucleolus. Increased nuclear-cytoplasmic ratio. 


\section{Walter Strupler}

The nasal cavity, including the system of the para-nasal sinuses, the inner region of the throat (except the vocal cords) and the lower respiratory tract are lined with a ciliated columnar epithelium with fairly numerous goblet cells.

In general the cells of both epithelia are to be recognized without difficulty. The columnar cells degenerate rapidly, and therefore to identify them careful attention must be given to the chromatin patterns of the nuclei, which are finely granular and regular in these cells.

Dense clusters of columnar cells viewed co-axially, that is, as they would be seen from above, looking down at their massed ends, often are difficult to identify. I would now like to describe the individual cells as we find them in our examination. First come the

Pavement cells: thin, large, polygonal cells with a round vesicular or a small dark pyknotic nucleus. The superficial elements tend to stain more acidophilic than the cells from the deeper layers which have a more basophile character. Cells from the basal layer are not only more basophile, but their nuclear-cytoplasmic ratio is increased. Parabasal and basal cells may occasion some difficulties in interpretation for the inexperienced investigator. Probably these cells only occur in bronchial secretions if a lesion of the lining mucosa is present, for example following bronchoscopy, biopsy or ulceration.

The columnar cells are cylindric or wedge-shaped cells with a rather excentric parabasally located nucleus and a very distinct opposite cell border which is often ciliated. Goblet cells are scattered between the ciliated elements. They are characterized by a goblet shaped foamy cytoplasmic body, with a basal, mostly pyknotic nucleus.

A differentiation between alveolar cells and histiocytes cannot always be made with absolute sureness. Therefore both are called alveolar-histiocytes, or simply histiocytes or macrophages. Some forms are well known, such as the "dust cells" with their oval or round or kidney shaped excentric nucleus and foamy irregularly vacuolated cytoplasm. They contain ingested mineral particles, for example carbon dots. Beside the small type of histiocytes without ingesta, these cells are encountered most frequently. In pathological conditions such as lung-infarction, bleeding and heartfailure the so-called "heart-failure-cells", which contain hæmatin, occur in the sputum. In lipoid-pneumonia or after a bronchography with an oily contrast medium or after application of oleous drugs "fat- or myelin-cells" may be found in the smears.

A special group of histiocytes is formed by the epithelioid cells and the foreign body giant cells (for instance the Langhans-, the Sternberg-giant cells).

In conformity with the classification of the broncho-pulmonary tumours by von Albertini we have to expect the following epithelial new growth in the respiratory tract: 


\section{The Cytological Examination of Bronchial Secretion}

13.

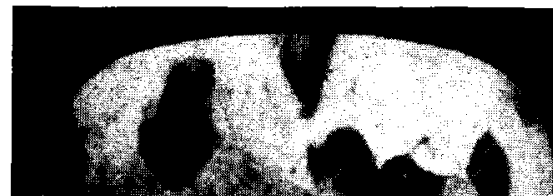

14.

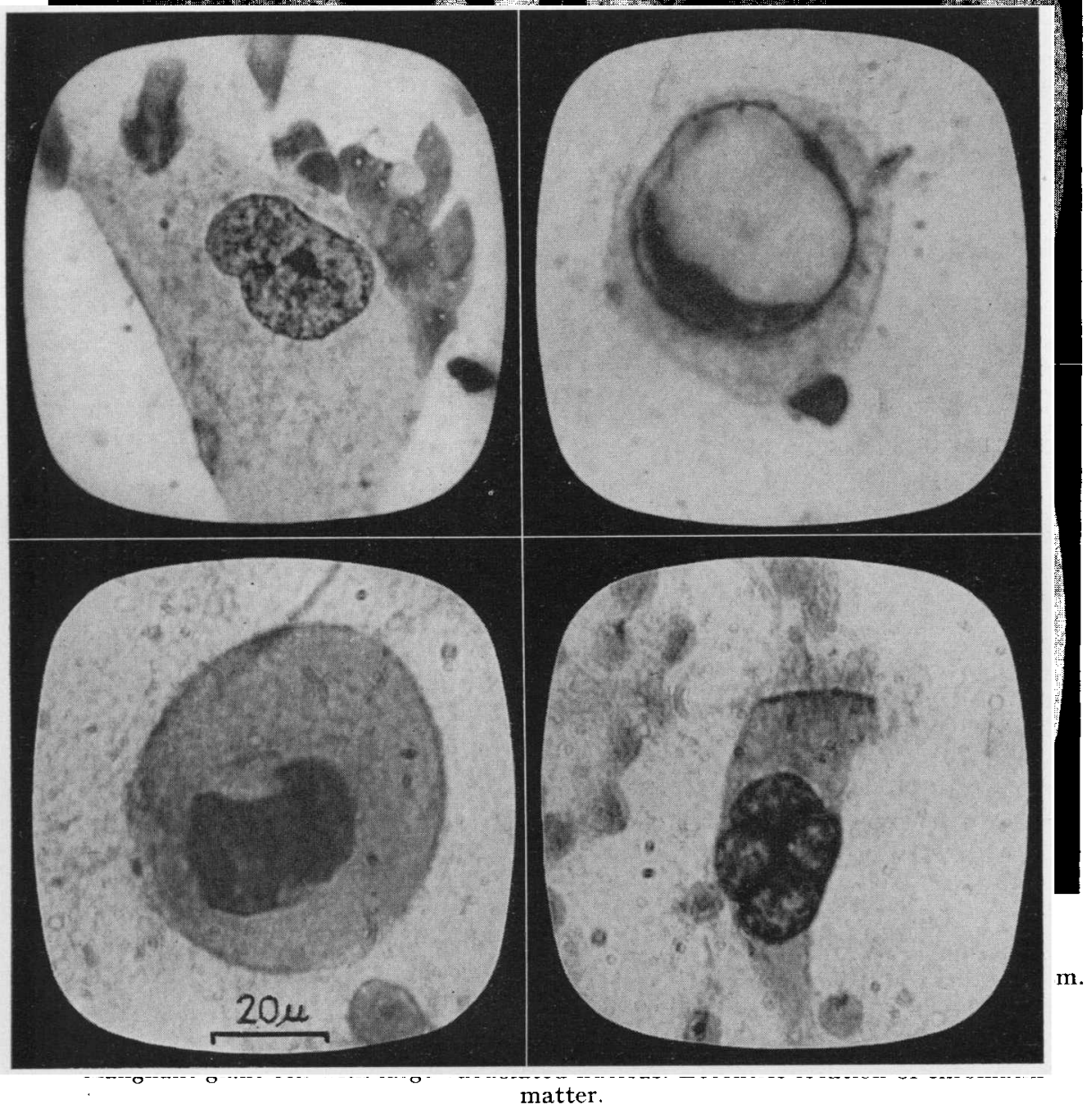

FIG. I 5 .

Squamous carcinoma. Round giant cell with slightly edged dark nucleus. Irregular dense chromatin pattern. Abundant cytoplasm with well defined border.

FIG. 16.

Ciliated multinucleated giant cell of columnar epithelium. No evidence of malignancy. Regular nuclear pattern; even shaped nuclei. 


\section{Walter Strupler}

the adenoma

the carcinoma

differentiated types such as:

adeno-carcinoma

cylindrocellular type

papillary type (the mucous forming type included)

pulmonary adenomatosis

squamous cell carcinoma

epidermoid type

anepidermoid type

undifferentiated type: large- to medium-sized cell carcinoma; anaplastic type or small-cell (including oat-cell) carcinoma.

The cytological diagnosis of cancer is based mainly on structural aberrations of cells and especially of their nuclei.

The preponderant nuclear changes are:

I. An alteration of the nucleo-cytoplasmic ratio by disproportionate increase of the nuclear size. As a rule a ratio above $\mathrm{I}: 3$ is suspicious of cancer.

2. Hyperchromasia as a consequence of augmentation of the chromatin matter. High basophilia results from the increase in nucleic acids in the active neoplastic nuclei.

3. Pathological structure of the nuclear pattern: elongation and irregularity of the borders.

4. Irregular distribution of chromatin, large granules, clumps, polar or excentric location.

5. Multiplication of nucleoli or enlargement of their size. Nucleolarnuclear ratio above $\mathrm{I}: 5$ causes some suspicion.

6. Multinucleation with nuclear atypia as a result of mitotic or amitotic karyokinesis without division of the cell.

Sometimes the cells assume syncytial aspect.

7. Mitotic activity is not only seldom encountered in normal cytology but is also rare in tumour cytology. This is probably an expression of the fact that in the superficial layers mitotic activity has obviously decreased. In primitive tumours and in clusters of not highly differentiated carcinoma abnormal mitotic figures are a little more frequent.

8. Degenerative changes are often seen in epidermoid malignancy. After irradiation abnormal vacuolation, fading and resorption of the nucleus is found.

The cytoplasmic changes have a less important diagnostic value than those of the nucleus.

I. Atypical vacuolation of cytoplasm often occurs in adenocarcinoma, although it is also encountered in epidermoid carcinoma and other cancerous cells. 


\section{The Cytological Examination of Bronchial Secretion}

2. Changes in staining reaction: pronounced basophilia of large, non flattened cells is suspicious of cancer. High acido- or orangeophilic coloration of somewhat differentiated cells of bronchial secretions is suggestive of malignancy.

3. Cytoplasmic inclusions (such as micro-organisms, blood-cells or cellular debris pigment granules, etc.) are of differential diagnostic importance.

Phagocytosis by histiocytes is a very common feature. Leucocytic inclusions are present most frequently in adenocarcinoma, but they may be found in other malignancy as well.

Changes of a cell as a whole: cellular hypertrophy and giant cells arouse suspicion if nuclear abnormality is present. Enormous difference in cellular size is seen in differentiated epidermoid carcinoma. Highly varying forms are found such as fibre cells, fish-cells, tadpole cells, snake-cells and other bizarre shaped elements.

Necrosis is very frequent. Degenerative cell changes occur in bronchial secretion especially in cases of adenocarcinoma. If small or larger tissue fragments or clusters are present in a smear, some tumour-criteria may be better judged by evaluation of the interrelationship of the cells and a comparison of their size (irregular pattern; anisocytosis; anisokaryosis; lack of distinct boundaries; density of grouping; engulfment; grouping in typical structure (acinus, etc.).

\section{BIBIJOGRAPHY}

Albertini, A. v. (I943) Vjschr. naturf. Ges. Zurich, 88, 225.

—_ (1945) Schweiz. Z. Path. Bakt., 8, 298.

—_- (I948) Schweiz. med.Wschr., 78, 717.

—— (195I) Ibid., 81, 659.

- (1952) Verh. dtsch. Ges. Path, 35, 54.

Ayre, J. E. (I944) Canad. med. Ass. J., 51, 17.

-__ (1946a) Amer. J. Obstet. Gynec, 51, 743.

-_ (1946b) Sth. med. J., (Bgham, Ala.), 39, 847.

- (1947a) Amer. J. Obstet. Gynec., 53, 609.

(1947b) Ibid., 54, 363 .

(1948) J. Amer. med. Ass., 138, I I.

(1950) Pr. méd., 58, I 44

and Bavld, W. A. G. (1946) Science, 103, 44 I.

and Kearns, P. J. (1945) Amer.J. Obstet. Gynec., 50, Iо2.

and Dakin, E. (1945) Canad. med. Ass. J., 53, 63.

- _ (1946) Ibid., 54, 489.

Barrett, N. R. (1938) J. thorac. Surg., 8, I69.

Bezançon, F., and IsRaEkls d)E Jong, S. (I9I3) Traité de l'examen des crachats. Paris.

Clerf, L. H., and Herbut, P. A. (I946) Ann. Otol. (St. Louis), 55, 646. (1952) J. Amer. med. Ass., 130, 793.

, and Nealon, 'T. F., Jr. (I95I) Ann. Otol. (St. Louis), 60, 840. 


\section{Walter Strupler}

Delarue, J., and Orcel, L. (I952a) Sem. Hôp. Paris, 28, 1026.

- - -

- - Paillas, J., Bergeron-Blondel, and Giocobi (I948) Ibid., 56, 580 .

313.

Dijkstra, B. K. S. (195I) Ned. T. Geneesk., 95, 3627.

Dudgeon, L. S., and Barrett, N. R. (I934) Brit. J. Surg., 22, 4.

- and Wrigley, C. H. (I935) J. Laryng., 50, $75^{2}$.

Escher, F. (1952a) Arch. ital. Otol., 63, i I3.

-__ (1952b) Z. Laryng. Rhinol. Otol., 31, 428.

-

FARBER, S. M. (I95I) Laryngoscope (St. Louis), 61, 602.

- - - Benioff, M. A., and McGrath, A. K., Jr. (I949) Radiology, 52, 5 I I

, Rosenthal, M., Alston, E. F., Benioff, M. A., and McGrath, A. K., Jr.

(I950) Diagnosis of Lung Cancer. Springfield, Ill.

Ferguson, J. H. (1949) Cancer (N.Y.), 2, 845.

Fremont-Smith, M., and Graham, R. M. (1946) The Diagnosis of Uterine Cancer by Vaginal Smear. New York. and Meigs, J. V. (1948) J. Amer. med. Ass., 138, 469.

Fried, B. M. (1947) Arch. intern. Med., 79, 29 I.

- (I948) Bronchiogenic Carcinoma and Adenoma, Baltimore.

FRIEDMANN, I. (I95I) J. Laryng., 65, I.

Gates, O., and Warren, S. (I947) A Handbook for the Diagnosis of Cancer of the Uterus by the use of Vaginal Smears. Cambridge, Mass.

Gowar, F. J. S. (1943) Brit. J. Surg., 30, I93.

Graham, R. M. (1947) Surg. Gynec. Obstet., 84, I66.

_- and Meigs, J. V. (I949) Amer. J. Obstet. Gynec., 58, 843.

___-, et al. (1950) The Cytological Diagnosis of Cancer. Philadelphia and London.

Grunze, H. (I955I) Klinische Zytologie der Thorax-krankheiten. Stuttgart.

- (1955a) Zytologie. In Handbuch der inneren Medizin. Berlin. Vol. 4.

Hampelin, P. (1919) Mitt. Grenzgeb. Med. Chir., 31, 672.

HAMPERL, H. (I950) Wien. klin. Wschr., 62, Io9.

Hartmann, P. (I955) Die Cytologie des Bronchialsekretes. Stuttgart.

- - Greven, H., and Drewes, J. (1953) Z. Laryng. Rhinol. Otol., 32, 577.

Heckner, F. (1952) Dtsch. med. Wschr., 77, 537.

Hengstmann, H., and Wittekind, D. (I950) Med. Klin., 45, 463.

Herbut, P. A., and Clerf, L. H. (I946a) J. Amer. med. Ass., 130, 1006.

- _- (1946b) Med. Clin. N. Amer., 30, 1384.

Holinger, P. H. (1950) Pract. oto-rhino-laryng. (Basel), 12, 236.

- - Hara, H. J., and Hirsch, E. F. (1945) Ann. Otol. (St. Louis), 54, 5.

Hutzinga, E. (I950a) Ann. Oto-laryng. (Paris), 67, 395.

-__ (1950b) Ibid., 67, 743.

- - and Iwema, J. (I95I) Ann. Otol. (St. Louis), 60, 290.

Isbell, N. P., Jewett, J. F., Allan, M. S., and Hertig, A. 'T. (1947) Amer. J. Obstet. Gynec., 54, 576.

Jackson, E., Bertoli, F., and Ackerman, L. V. (I95I) J. thorac. Surg., 21, 7.

Josselin DE Jong, R. DE (1929) Ned. T. Geneesk., 73, 3636.

KAHLAU, G. (I950) Klin. Wschr., 28, 574.

Keuning, F. J. (195I) The Cytologic Diagnosis of Bronchogenic Carcinoma from Bronchial Secretions and Sputum. Groningen. (manuscript.)

KISSLING, K. (I95I) Dtsch. med. Wschr., 76, I645.

Lemoine, J. M., and OrCel, L. (I948) Bronches, 1, 223. 


\section{The Cytological Examination of Bronchial Secretion}

Levaditi, G., and Kreis, B. (I949) Techniques de Laboratoire en Pneumologie. Paris.

Libersat, G. (I95Ia) Considérations sur le diagnostic des epithéliomas des voies aéro-digestives supérieures. Thesis, Bordeaux.

—_- (I95I I ) Rev. Laryng. (Paris), 72, 6г 2.

Liebuan, E. (I946) Schweiz. med. Wschr., 76, 1344.

Lopes Cardozo, P. (1950a) Ned. T. Geneesk., 94, 1635.

(1950b) Ibid., 94, $275^{8 .}$

(1954) Clinical Cytology. Leyden.

and Janssex, C. A. L. (1950) Ned. T. Geneesk., 94, 23 I8.

Martella, E. (1952) Atlante di Citodiagnostica del Carcinoma dell' Utero. Naples.

MCCltre, G. W. (1947) W. Va med. J., 43, 66.

Meigs, J. V. (1947a) J. Amer. med. Ass., 133, 75.

-... (1947b) Surg. Gynec. Obstet., 84, 249.

- - Graham, R. M., Fremont-Smith, M., Kapnick, I., and Lawson, R. W. (1943) Ibid., 77, 449 .

- —, , Janzer, L. T., and Nelson, C. B. (1945) Ibid., 81, 337.

Монк, Н. J. (1949) Dtsch. med. Wschr., 74, I 463.

, and TöbBeN, A. (1952) Ibid., 77, 420.

Nalmann, H. H. (1952) Arch. Ohr.-Nas.-u. KehlkHeilk., 161, 290.

—_ (1953) Münch. med. Wschr., 95, 770.

OchsNer, A. (1953) Laryngoscope (St. Louis), 63, 7oo.

O'KeEfe, J. J. (I950) Ibid., 60, 93 I.

Osbors, G. R. (1953) Applied Cytology. London.

Papaxicolaou, G. N. (1928) Proc. 3 rd Race Betterment Conf. p. 528.

- (1942) Science, 95, $43^{8}$.

(1946) J. Amer. med. Ass., 131, $37^{2}$.

(1949) Amer. J. clin. Path., 19, 30 I.

(1954) Atlas of Exfoliative Cytology. Cambridge, Mass.

and Koprowska, I. (I95I) Cancer (N.Y.), 4, I.

-_.., and Traut, H. F. (I94I) Amer.J. Obstet. Gynec., 42, I93.

York.

(I943b) Diagnosis of Uterine Cancer by the Vaginal Smear. New

- _ - and Marchetti, A. A. (1948) Epithelia of Woman's Reproductive

Organs: a Correlative Study of Cyclic Changes. New York.

Povcard, A., et al. (1955) Tumeurs Broncho-Pulmonaires. Paris.

Quexsel, L. (I928) Zytologische Untersuchungen von Ergüssen der Brust-und

Bauchöhlen mit besonderer Berücksichtigung der karzino-matösen Exsudate.

Stockholm.

Ruxge, H. (I954) Beitrage zur Krebsforschung. Dresden and Lpz. Vol. 4.

SAlzer, G., et al. (1952) Das Bronchuscarcinom. Wien.

Saxty, P., Berari, M., and Galy, P. (I95I) J. Méd. Lyon., 32, 4 I.

- et al. (I953) Bronches, 3, 5.

SHORR, E. (I94I) Science, 94, 545.

Sierixg, H. (1952) Dtsch. Arch.klin. Med., 199, 443.

Soulas, A. (1953) Pr. méd., 61, I75I.

Streicher, H. J., and SANdK̈̈̈LER, S. (1953) Klinische Zytologie. Stuttgart.

Strupler, W. (I950) Prat. oto-rhino-laryng. (Basel), 12, 257.

-_-, (I955) Die Zytologie des Tracheo-Bronchialsekretes. Advances in OtoRhino-laryngology. Basle. New York.

Vincent Memorial Hospital (1950) The Cytologic Diagnosis of Cancer. Philadelphia and London. 


\section{Walter Strupler}

De VRies, M. J. (1954) The Cytology of Primary Bronchus and Lung Carcinoma. Thesis, Leyden.

Wandali, H. H. (1944) Acta chir. scand., 91 (Suppl. 93).

Watson, W. L., Cromwell, H., Craver, L., and Papanicolaou, G. N. (I949) J. thorac. Surg., 18, I 13.

WEGELIN, C. (1942) Schweiz. med. Wschr., 23, I053.

Wespi, H. J., and Strupler, W. (1948) Gynaecologia, 126, 197.

Wittekind, D. (i95o) Med. Klin., 45, 858.

Woolner, L. B., and McDonald, J. R. (1947) Proc. Mayo Clin., 22, 369.

_ _ _ (1949a) Surg. Gynec. Obstet., 88, 273.

- - - (1949b) J. Amer. med. Ass., 139, 497.

Wuhrmann, F. (1937) Münch. med. Wschr., 84, 860.

ZADEK, I. (I933) Zytologie der Exsudate und Trans-sudate. In Handbuch der allgemeinen Hæmatologie. Berlin., 1, I 373 .

_ 